\title{
Looking for the Party? The Effects of Partisan Change on Issue Attention in UK Acts of Parliament
}

\begin{abstract}
:
Political parties matter for government outcomes. Despite this general finding for political science research, recent work on public policy and agenda-setting has found just the opposite; parties generally do not matter when it comes to explaining government attention. While the common explanation for this finding is that issue attention is different than the location of policy, this explanation has never truly been tested. Through the use of data on nearly 65 years of UK Acts of Parliament, this paper presents a detailed investigation of the effect parties have on issue attention in UK Acts of Parliament. It demonstrates that elections alone do not explain changes in -the distribution of policies across issues. Instead, the parties' organizations, responses to economic conditions, and size of the parliamentary delegation influence the stability of issue attention following a party transition.
\end{abstract}

Keywords: parties; issue attention; Britain; agenda-setting 
The increased attention of agenda-setting research on partisan politics has often been at odds with the belief that parties drive politics. For example, recent literature finds little evidence of issue ownership (e.g. John et al 2014) or a strong election effect (Baumgartner et al 2009) on the content of political agendas. From this perspective, parties' largest differences are in how they use the political process (e.g. Bevan et al 2011; Jennings et al 2011a). Partisan differentiation on issues is at best one source of policy variation (e.g. Baumgartner et al 2009). These weak findings with respect to the impact of parties in agenda-setting research have been explained through the relatively stable nature of policy attention across issues, despite the multitude of research demonstrating the importance of political parties in politics more broadly.

In contrast to the findings for policy attention, scholars show that political parties play a prominent role in everything from party manifestos and elections (e.g. Adams 1999; LewisBeck and Stegmaier 2000; Dalton 2008; Adams and Somer-Topçu 2009; Somer-Topçu 2009; de Vries and Hobolt 2012), to government formation and termination (e.g. Müller and Strøm 2000). Moreover, evidence of their effects on legislative behavior (e.g. Huber 1996; Döring 2003), policy outcomes (e.g. Hibbs 1977; Alesina and Rosenthal 1995; Schmidt 2006), institutional reform (e.g. Cox 1987), and oversight of policy implementation and the bureaucracy (e.g. Huber and Shipan 2002) demonstrates the importance of political parties in policy-making. Nevertheless, research on public policy and budget outcomes indicates only mixed evidence for parties' relevance (Alt and Lowry 2000; McAtee et al 2003; Soroka and Wlezein 2010). When it comes to issue attention ${ }^{1}$ however, agenda-setting research would argue that parties in government maintain a certain level of attention on issues due to world

\footnotetext{
${ }^{1}$ Issues are "topic[s]... [that define] support among electors..." or shift support between parties (Budge 1993, 43). Issue attention therefore refers to the relative level of focus on a topic that is consequently important to groups within society such as the environment.
} 
events, political and economic systems and also respond to opposition critiques (see GreenPedersen and Mortensen 2010; Seeberg 2013). Attention to an issue and the direction of policy on that issue are clearly two different things that help explain the differences in the findings of these two literatures, but how accurate is this agenda-setting explanation and more importantly, how robust are the non-findings concerning parties in the agenda-setting literature when the analysis takes into account parties' specific organizational characteristics and dynamics? As complex organizations balancing multiple goals (Strøm 1990), parties' influence on the government agenda ${ }^{2}$ likely depends on their decision-making structures and strategic context. We develop a theory of aggregate partisan influence that focuses on the factors determining the impact of parties' internal decision-making process, contextual demands for policy, and parties' legislative ability to influence policy.

To examine the extent of party effects on changes in issue attention we use data from the UK Policy Agendas Project (www.policyagendas.org.uk) on UK Acts of Parliament from 1945 to 2008 . In particular, we study differences in the level of attention to issues by a-party Commented [sb1]: This should remain by party. It is like saying we separate our sample by gender. through time series analyses aimed at pinpointing party influence from differences in party organization, elections and institutional control, using a new measure of the parliament's aggregate level agenda stability introduced by Mortensen et al (2011). This measure compares the differences in attention, issue by issue, creating an overall index of stability in issue attention from year to year. The results show a clear pattern of revisions to laws by newly elected governments suggesting an aggregate process of policy change following party transitions. This aggregate approach complements the issue-by-issue research that finds only limited partisan influence by placing each issue in the broader context of policy change. It also builds on similar work focused on understanding aggregate patterns of issue attention

\footnotetext{
${ }^{2}$ The government's agenda refers to the distribution of policies enacted within a year across issues.
} 
(e.g. Jennings et al 2011b; Boydstun et al 2014). Specifically, we find evidence that for incumbent governments a poor economy, a larger legislative majority and a long tenure in office encourages governments to stick to a consistent legislative program. However, transitions that occur in rough economic times and new governments with large legislative majorities decrease the stability of attention across issues. Decreased agenda stability following a party transition indicates a change in issue attention from the previous government. This change implies a substantive difference in parties' prescriptions across issues for an ailing economy. However, large party memberships increase stability as more member dominated parties are less able to institute radical changes in issue attention.

The findings in this paper hold important implications for democratic government and electoral accountability. Given the predominance of parties in advanced democracies, how can voters influence government policies if the government's agenda does not change following a partisan transition? This means that when the partisan control of the cabinet transitions-changes the new government focuses on different issues than the previous government. Optimistically, our analysis indicates that parties provide voters with meaningful choices across important issues.

The rest of this paper takes the following form. First, we discuss several of the more commonly found (or unfound) party effects seen through policy, issue attention and policy processes. Second, we consider these observations in light of the agenda-setting literature and offer several expectations for how and when parties will demonstrate an effect in the agendasetting process. Next, we discuss the data that we use to test our hypotheses and present our analysis that tests each proposed party effect. Finally, we conclude the paper with a brief summary and consider how (or how not) to look for the effect of parties in public policy and policy agendas.

\section{Party Effects: Policy, Attention or Process}


Political party influence has been studied in a variety of contexts related to public policy and policy outcomes. Much of this research looks at the effect of party governments on social and economic policies (Schmidt 2006). From the perspective of party policy accountability, this literature points out important differences in the types of policies that parties develop in office. Parties' policies depend on the preferences of their historical constituencies (Hibbs 1977; Hicks and Swank 1992; Alesina and Rosenthal 1995; Tsebelis 2002). However, linking specific political parties to policy outcomes is difficult in many democracies because single party governments are unusual and parties' preferences are put through complex, multi-layered institutional contexts (Tsebelis 2002; Schmidt 2006).

Furthermore, changing public opinion and feedback loops between public policy and opinion complicate leaders' responses to public demands (Soroka and Wlezien 2010). Even under divided government parties seek to draw economic policies in their preferred direction (Alesina and Rosenthal 1995). Alt and Lowry (2000) demonstrate that parties in government allocate budgets according to their policy goals, although others contest their results (McAtee et al. 2003). Focusing on labour policies, Tsebelis (2002) adds that ideological disagreements between coalition parties and institutional constraints limit the amount of legislation that coalition governments generate. Furthermore, Huber and Shipan (2002) illustrate that party strategies influence the length and detail of legislation on health care policy across US States and labour policies cross-nationally. While these studies find some evidence that parties develop public policy in line with their preferences, they generally focus on a specific policy outcome based on Lipset and Rokkan's (1967) cleavage theory, such as social or economic policy, budget outcomes, or the total number of bills passed, without taking into consideration the government's broader attention to issues.

This perspective has been extended to suggest that parties 'own' issues related to their historical constituencies, policy preferences and experiences in government (Budge and Farlie 1983; Egan 2013). Issue ownership theory connects parties' electoral success to the salience 
of the issues that they own in the electorate. Parties that own an issue benefit by emphasizing that issue in their electoral appeals (Petrocik 1996). Parties develop ownership through their emphasis on issues when they come to office (Egan 2013). For example, socialist parties in Europe 'own' labour issues because they have historically organized on these issues and focused their resources on them in government. Following from this perspective, socialist parties will benefit when topics related to labour and employment are salient and will presumably focus attention on these issues in office to maintain an image of competence (Carey 2009). Therefore, a socialist party shifts the government's issue attention to place greater emphasis on labour issues. The traditional issue ownership or cleavage based approach to party politics largely assumes a mostly fixed type of policy emphasis from a party over time, although empirical evidence suggests that the issues voters attribute to parties' primary competencies is frequently incomplete or inconsistent and can change over time (Bélanger and Meguid 2008). Furthermore, parties' historically 'owned' issues provide little guidance for the substance or quality of the policies parties pursue once they enter into office (Egan 2013).

Research from an agenda-setting perspective, however, has found less evidence that parties play an influential role in determining levels of issue attention in various government outputs such as executive speeches, laws and budgets. This focus on issue attention is not too dissimilar from the expected effects of cleavages or issue ownership on bill productivity (Lipset and Rokkan 1967; Budge and Farlie 1983; Petrocik 1996), but the empirical results from the agenda-setting literature are at best mixed (e.g. Baumgartner et al 2009; Jennings et al 2011b; John et al 2014). From the agenda-setting perspective, political and economic conditions limit the government's ability to focus attention on strictly partisan goals (GreenPedersen and Mortensen 2010). Like research from a party politics perspective, this work emphasizes the role of institutional structures that limit parties' ability to advance their most preferred policy goals (Jennings et al 2011a; Bevan et al 2011). For example, in institutional 
contexts with a large number of parties in parliament and in which minority governments regularly occur, the government often undertakes policy salient to opposition parties (Seeberg 2013). Overall, this literature indicates the institutional and contextual reasons why we may expect a lack of partisan effects. We add that a fuller explanation of party influence would consider how internal organizational characteristics may influence the government agenda.

Neither the party politics nor the agenda-setting approaches suggest that parties play an unimportant role in the government process. Parties are the primary organizations controlling governments in advanced industrial democracies. However, studies from these perspectives find contrasting and mixed evidence of their substantive impact. This inconsistency may exist from differences in the operationalization of the dependent variables, but the differences are likely to also reflect fundamental disagreements over the way in which each literature expects parties to matter. Tests of government accountability and cleavage based accounts often focus on trends linked to parties' electoral and policy strategies on a subset of issues or on the specific location of parties' preferences on traditional economic policies without fully considering the role of broader effects on their attention across a range of issues. Agenda-setting explanations regularly focus on broader processes that influence the greater distribution of attention across issues, but avoid directly specifying the issues on which parties most likely differ (e.g. Jennings et al 2011b). To explain these differences, we examine the government's agenda stability or the change in the distribution of attention across issues from year to year (see Mortensen et al 2011). By studying agenda stability we seek to isolate the effect of party differences without having to directly specify or impose our assumptions of parties' priorities on each issue. In particular, we develop a series of hypotheses that link parties' organization and policy strategies to agenda stability.

\section{Hypotheses: Maintaining Stability}


Studies of policy responsiveness and agenda-setting frequently predict differences in which policies parties pursue in office based on their issue priorities and political context. However, these accounts may miss parties' influence on the policy agenda if they focus only on the broad differences in party preferences and ignore the organizational and contextual factors that lead to the formation of those preferences. To reconcile these approaches, we add that parties are dynamic and strategic organizations that face competing pressures on their agenda. In addition, differences between parties will lead to the most dramatic changes in agenda stability immediately following changes in control of government. Overall, our approach traces parties' decision-making processes from intra-party politics, the external demand for policy change, and finally, parties' parliamentary control.

Research on party behavior and public policy often treats parties as if parties are unified organizations in which internal decision-making processes are unimportant for understanding their behavior. However, as organizations, parties face demands from multiple groups within the party that potentially contain divergent policy goals, such as activists, elected representatives and organized factions (Harmel and Janda 1994; Ceron 2013; Greene and Haber forthcoming). Scholars find that pressures on party leadership stemming from regional party groups, intra-party factions or organizational influences affect numerous outcomes, such as the party's platform (Harmel and Tan 2003) and parliamentary behavior (Huber 1996; Laver 1999; Carey 2009). The preferences of intra-party groups constrain party leaders most as an election nears (Ceron 2013). Empirically, internal divisions often lead to changes in parties' election campaigns and parliamentary behavior (Ceron 2013; Greene and Haber forthcoming).

Parties' organizations are more fluid than much research assumes. For example, party memberships have declined throughout much of Western Europe (Tan 1997), internal candidate selection rules vary within countries over time (Shomer 2014), members of parliament switch parties with some frequency (O'Brien and Shomer 2013), and the degree of 
internal disagreements vary over time based on the electoral context both in parliament and at the parties' own national meetings (Hug and Shultz 2007; Greene and Haber forthcoming).

More broadly, parties have generally democratized candidate selection rules and increased the party leaders' selectorate (Kenig 2009).

Like other organizations in Western Europe, parties in the United Kingdom have also undergone organizational changes. Parties have experienced declining memberships, although this decrease is not monotonic (Tan 1997). For example, Labour reversed the trend in the 1990s (Whitely and Seyd 2002). Consequently, activism by individual members declined over the last half century (Seyd and Whiteley 2004). As a response, both Labour and the Conservatives increased grassroots members' ability to influence the party’s leadership selection (Cross and Blais 2012). This trend is essential given that six of the last ten prime ministers prior to 2008 took office without a general election (Kenig 2009). Importantly, surveys of party members in the UK indicate that a primary motivation for membership is personal feelings of efficacy from intra-party influence on the policy priorities of the party leadership (Seyd and Whiteley 1992; Whiteley et al. 1994).

Building on this research, we theorize that party organizations hold implications for intra-party politics and consequently the stability of the party's issue attention in government (see Mortensen et al 2011). Motivated by policy goals, party members tend to hold more extreme preferences than party leaders and the general electorate (Seyd and Whiteley 1992; Whiteley et al. 1994; Schofield and Sened 2006). Furthermore, in mass parties, such as in the UK, party leaders are heavily reliant on larger party memberships, but rely on less intensive membership campaign tactics when the number of members declines (Schofield and Sened 2006). This leads us to predict that a party's internal dynamics and the intra-party leader's selectorate will influence party leaders' decision-making in office (Harmel and Janda 1994). Decreases in the numbers of party members in the UK have freed party leaders to adapt their electoral appeals to be more responsive to potential voters (Seyd and Whiteley 2004; 
Schofield and Sened 2006). For example, Seyd and Whiteley (2004) describe this tradeoff for Labour in 1983 (on to nuclear weapons, public ownership and public housing) and the Conservatives under John Major (the 'back to basics' programme of social and moral conservatism) in which both parties proposed policies which were much more in line with the preferences of their members than those of their broader potential electoral supporters.

More broadly, we argue that change in intra-party politics, such as the number of party members, influences the ability of the party to maintain a stable platform. Intra-party volatility limits parties' ability to maintain a stable agenda or a similar focus on issues year after year. Parties that dramatically lose members face the challenge of attracting new groups while appeasing the traditional core groups within the party (Kitschelt 1989).Party leaders depend on intra-party groups' support to organize election campaigns and manage the party organization and must respond to their members' goals (Seyd and Whiteley 1992; Schofield and Sened 2006; Cross and Blais 2012; Schumacher 2013; Schumacher et al 2013). Party members often hold more extreme preferences than leaders (Whiteley and Seyd 1992; Seyd and Whiteley 1994) and are less willing to compromise their policy goals to win elected office (Schofield and Sened 2006). Furthermore, party leaders depend more on the electoral support of the party's organization when a party holds a larger membership (Seyd and Whiteley 2004; Schofield and Sened 2006; Schumacher 2013). Based on this research, we assume that when party members have greater influence because of their size party leaders will be less likely to make major changes in issue attention. ${ }^{3}$ Our first hypothesis combines this organizational decision-making logic to the level of agenda stability.

\footnotetext{
${ }^{3}$ Note that we are discussing the concept of policy priorities and not the location of members' preferences. While there are clear contexts in which intra-party groups' preferences diverge (see for example Hug and Schultz 2007; Ceron 2012 and 2013; Greene and Haber
} 
H1) Higher party membership increases agenda stability.

As strategic actors, party leaders act to balance their policy goals with goals for winning elections and controlling office (Strøm 1990; Adams 1999; Spoon 2011). For example, parties change their policy preferences or discuss new issues as an electoral strategy (-Adams and Somer-Topcu 2009; Somer-Topcu 2009; de Vries and Hobolt 2012). Models of electoral competition assume that parties develop policy in office that is consistent with the goals of their voters to avoid appearing unaccountable (Downs 1957; Adams 1999). Scholars find that this appearance influences much of parties' behavior in parliament, such as the application of parliamentary procedures (Huber 1992; 1996), roll call votes (Carey 2009) and parliamentary questions (Vliegenthart and Walgrave 2011).

Following from this literature, we add that the factors which influence parties' electoral calculus, such as the economy, are likely to also impact the parliament's issue attention in a chamber dominated by a single party. Parties change their electoral strategies based on information they have about their potential electoral success. They use signals such as the state of the economy or public opinion to craft their electoral messages (Adams et al. 2009; Soroka and Wlezien 2010; Williams et al. forthcoming; redacted). Substantial literature finds that governing parties expect voters to punish them for poor economic performance (Powell and Whitten 1993; Whitten and Palmer 1999; Lewis-Beck and Stegmaier 2000). When parties expect to do well, they see little reason to meddle with their electoral strategy, whereas parties that expect to lose or decrease votes alter their strategies more dramatically (e.g. Adams and Somer-Topcu 2009; Somer-Topcu 2009). Economic conditions also

forthcoming), agenda stability will be mostly influenced by differences in how parties allocate their attention across issues. 
influence the levels of intra-party disagreement; negative economic conditions increase the range of preferences expressed at party national meetings for incumbents and decrease disagreement for opposition parties (Greene and Haber forthcoming). Furthermore, Williams et al. (forthcoming) present compelling evidence that incumbent parties responsible for declining economic performance place greater attention on economic issues in their election campaigns. Governments also show greater attention to economic policy relative to other issues when the economy is salient (Jennings et al. 2011b).

The government's agenda also reflects parties' electoral goals. Parties may change the focus of their attention when economic signals indicate that voters will hold them responsible. Parties fear punishment for appearing incompetent, inactive or unconcerned when the economy declines. However, a strong economy allows parties to pursue their planned agenda without fear of punishment, as voters consider them more competent on a range of issues (Green and Jennings 2011a; 2011b). Poor economic conditions, therefore, lead to greater agenda stability across issues as the government limits its attention to economic policies, ${ }^{4}$ but becomes less stable as the government focuses on a broader range of problems when the economy improves. This argument follows from related findings on the effect of the level of the government's economic focus on the ability to attend to other issues (Jennings et al 2011b) and is consistent with Green-Pederson and Mortensen's (2010) finding that parties respond to economic conditions in office. ${ }^{5}$ Our second hypothesis summarizes this logic.

\footnotetext{
${ }^{4}$ Agenda stability does not mean that parties are inactive, but on the contrary, signals that they are dedicating their resources and attention to the specific issues they believe will solve the economic situation.

${ }^{5}$ While agenda setting research has emphasized economic conditions as important in the past, these explanations were often posed as evidence of a lack of party influence. Party politics researchers, however, consider the economy as an important driver of parties' election
} 
H2a) A poor economy increases agenda stability.

However, this relationship reverses following a partisan transition. Parties with alternate ideological prescriptions for the economy will see little reason to address the economy in the same way as their fallen competitor. Instead, the new party in power faced with a poor economic situation will substantially shift the agenda towards its set of economic solutions. For example, the Labour Party may choose to focus its attention to issues related to workers' benefits under a weak economy, whereas the Conservative party would instead choose to address regulations on business groups (Hibbs 1977). Therefore, the following hypothesis adds party transitions as a moderating factor for the effect of economic conditions on agenda stability;

H2b) A poor economy decreases agenda stability following a partisan transition

In addition to intra-party politics and responses to economic conditions, the government's ability to control parliament also influences agenda stability. Substantial literature finds that parties' ability to win votes in parliament plays an important role in determining their ability to achieve policy goals. Parties in parliaments with weak party discipline, when members of the same party frequently vote against the party leadership's proposals, are limited in the range of policies they can pass by differences in the policy preferences of its own members (Carey 2009). Party leaders use various legislative procedures

campaigns and success (see for example Williams et al. forthcoming; Greene and Haber forthcoming). The novelty of our argument is to reinterpret the effect of economic conditions through the lens of party competition. 
to encourage party members to vote in a certain way, such as attaching votes of confidence to legislation, limiting amendments or by controlling the voting order in which proposals are presented (Huber 1992, 1996a; Döring 2001; 2003). Parliaments with procedures that provide leaders with substantial legislative control and consequently high levels of discipline should not face as many difficulties initiating their policy goals (Döring 2001; 2003; Bevan et al 2011). Despite the high levels of discipline in the House of Commons, we argue that British governments are also limited by their ability to pass Acts of Parliament. Since World War II Parliament averaged only 59 Acts per year. From this perspective, governing parties that hold a small majority may face the need for greater intra-party log-rolls or bargains to ensure complete party support for certain Acts. Larger parliamentary majorities allow the government to focus on its legislative agenda while still allowing for a certain degree of intraparty disagreement (Huber 1996) or in the case of the UK backbench rebellions.

This logic fits well with theories of party discipline that indicate that party leaders have more options for obtaining a majority in voting when the party has a large majority (e.g. Cox and McCubbins 1994; Cox 2000). Indeed, the procedures available to the prime minister in the House of Commons give the leadership substantial tools to encourage parliamentary discipline (Cox 1987; Döring 2001; 2003), but require majorities within parliament to support the passage of legislation. Despite high levels of parliamentary discipline, the leader of a party with a small legislative majority may be forced to offer policy concessions as inducements to members that might otherwise defect from the party line. Furthermore, in a first-past-the-post electoral system larger majorities include a greater number of actors within the party with a diverse range of electoral constituents. To maintain an appearance of party unity (Ceron 2013), party leaders may avoid forcing votes on contentious issues (negative agenda control) to protect MPs' and the party's future electoral success (Cox 2000; Martin 2004). The recent free vote on the Marriage (Same Sex Couples) Act 2013 where members were not instructed by their parties on how to vote demonstrates the caution that exists in the UK system. In 
general, the agenda will be more stable from this perspective when the governing party only needs to maintain the support of a fraction of its members, rather than all of them.

H3a) A larger parliamentary majority increases agenda stability.

Like Huber's (1996) finding on the timing of legislative procedures, new governments prioritize their electoral priorities early in the new legislative cycle (see also Martin 2004). Large majorities in this setting have an upper hand following a partisan transition. Party leaders require fewer procedures and inducements to find a majority on which intra-party consensus exists on an issue when the party holds a larger majority. Instead, parties with a smaller majority require greater intra-party bargaining and require greater time to enact their preferred policies. This perspective connects well to studies of coalition governance and policy change. Like governing coalitions, parties focus first on the easily negotiated policies before moving on to more contentious topics (Martin 2004). Larger majorities, therefore, quickly enact their policy priorities. A large majority, which includes a large number of new MPs, leads to a less stable agenda following a transition because of the contrast between the new government's and the outgoing party's agendas. The following hypothesis summarizes our expectation linking the size of the majority in parliament to agenda stability following a transition.

H3b) A larger parliamentary majority decreases agenda stability following a partisan transition.

Although we expect intra-party politics, economic conditions and parties' ability to control parliament to influence the government's agenda,_we add that elections and the partisan transitions that follow from them provide the greatest opportunity for partisan 
differences to arise. Elections provide voters with the opportunity to choose between parties with competing electoral platforms and policy proposals (Downs 1957). When a new party comes into power, parties seek to enact their policy proposals both because they sincerely value those goals and because they instrumentally value those goals so that they can win future elections by appearing accountable to voters (Strøm 1990). Once parties are in office, they may feel little need to change their policy focus. Assuming that parties' policy priorities remain stable in office, we predict that the agenda should become increasingly stable the longer a party controls the government.

H4) Time controlling government increases agenda stability.

\section{Data and Methods}

This paper focuses on the UK Policy Agendas Project Acts of the UK Parliament dataset from 1945 to 2008 and covers 19 major topic codes that encompass all the issues the UK Parliament deals with (see www.policyagendas.org.uk for the data and complete details concerning its coding). UK Acts of Parliament are the primary legislation enacted by the UK Parliament, which is headed by the prime minister and supported generally by a single party throughout this time period. ${ }^{6}$

We argue that the UK is a difficult test of our theory for a number of reasons. In particular, previous literature on the policy agenda has found little support for an effect of parties on policy attention (Jennings et al 2011a; Bevan et al 2011). Based on this literature, we would expect little or no evidence of party effects on agenda stability in the UK. High levels of party discipline in parliament and single party majorities mean that small changes in

\footnotetext{
${ }^{6}$ With the exception of the Labour minority government from February 1974 to October 1974 a majority controlled parliament from 1945 to 2008 .
} 
parties' organizations and parliamentary delegation should be less likely to have much of an impact, unless parliamentary leaders react to intra-party politics (Döring 2001; 2003). Given that many of our hypotheses predict an effect from within party differences (Cox 1987; 2000), rules favoring high levels of party discipline in parliament and that provide the cabinet with substantial control of the parliamentary voting agenda stack the deck against our theory. Although these same conditions make for a relatively weak test of the broad party matters thesis, we are quite confident that if we find evidence consistent with our hypotheses that we can make valid inferences to other parliamentary democracies with weaker levels of parliamentary discipline.

Using data from the UK Policy Agendas Project, we calculate a measure of agenda stability (see Mortensen et al 2011) as our dependent variable. ${ }^{7}$ Agenda stability captures the degree of similarity in the complete issue attention for Acts of Parliament across all issues from year to year. We calculate agenda stability using the following formula:

\footnotetext{
${ }^{7}$ Related research has focused on attention diversity summarizing the level of diffusion between issue areas in political agendas (see Jennings et al 2011b) using the most appropriate measure Shannon's H (see Boydstun et al 2014). While another important summary of political agendas, our interest in policy stability lead us to focus on a measure derived from Mortensen et al (2011). This measure allows us to be neutral about the types of issues parties address to look for systematic change in the aggregate agenda rather than the diversity of that agenda and the tradeoff between issues (see Jennings et al 2011). These indicators are clearly related, as a perfectly stable agenda from year to year would also exhibit a stable level of diversity. Empirically, the measures are only weakly related; the correlation between Shannon's H and our measure of agenda stability is 0.39 ; they are related, but also clearly different measures.
} 


$$
A S_{t}=100-\left(\sum_{i=1}^{n} \mid A c t s_{i t}-\text { Acts }_{i t-1} \mid\right) / 2
$$

Where Acts is equal to the percentage of acts in an issue at time $t$ and time t- 1 with the absolute value of the difference summed over all possible issues in the agenda (n). This value is divided by 2 as the maximum value is equal to 200 and the minimum value is 0 and is subtracted from 100 so that the agenda stability $(A S)$ is highest at 100 and lowest at 0 . Agenda stability therefore measures how consistent attention is across issues from one year to the next. If the exact same percentage of acts is devoted to each issue in year $t$ and $t-1$, agenda stability is equal to 100 . If every issue switches from some percentage to $0 \%$ and from $0 \%$ to some percentage then agenda stability is equal to $0 .^{8}$

Take for example a hypothetical parliament limited to passing only two acts of parliament each year. In this parliament, agenda stability equals 100 every year if both acts address the same issue, such as healthcare. If some shock occurred that caused the party to use one act for environmental policy (instead of healthcare), then agenda stability would drop to 50. Despite the same number of acts each year, this drop in stability indicates that the topics the government addressed changed. Agenda stability allows us to focus on the aggregate level of substantive changes in the issues included in acts over time without having to make strong assumptions about which issues new parties will emphasize.

The agenda stability of UK Acts of Parliament from 1945 to 2008 is presented in Figure 1. The x-axis, Parliamentary Year, indicates the year in which parliament opened for a

\footnotetext{
${ }^{8}$ Our measure of agenda stability is salience neutral, or 'non-directional'. Salience can increase or decrease on an issue and it will register as a change in attention stability. While this limits our ability to make strong statements about exact policy changes, it provides us with an aggregate indicator of how stable the attention of parties is across years, regardless of the direction of policy.
} 
new session with the Speech from the Throne. The start of a new parliamentary session occurs at the end of the calendar year or in May for years with an election (Jennings et al 2011a). In this figure, we note the majority party and partisan transitions with vertical dashed lines.

Elections not resulting in a transition are noted with vertical dotted lines.

[insert Figure 1 about here]

As Figure 1 shows there are no obvious patterns in agenda stability by party, elections or transitions from a visual inspection of the measure in the figure. ${ }^{9}$ It is however noteworthy how stable our measure of agenda stability tends to be. While there are clear cases when a party transition associates with decreased stability, the mean agenda stability of Acts of Parliament is clear and persistent over time. Specification tests of this measure revealed our measure of agenda stability to be white noise with a signal significant spike in both the autocorrelation and partial auto-correlation functions. ${ }^{10}$

To fully test our hypotheses, we make use of an auto-distributed lag model of agenda stability which includes a series of independent variables and interactions to account for the conditional nature of our hypotheses. The model also includes a lagged dependent variable to account for the time series nature of agenda stability. The first of our independent variables measures the number of registered party members in the electorate of the party in power (see

\footnotetext{
${ }^{9}$ As a robustness check, we include a dummy variable equal to one when the Conservative party is in government. This produced the same inferences for all our independent variables with the Conservative party dummy variable itself being positive but insignificant.

${ }^{10}$ As these specification tests are somewhat ambiguous we ran our analyses using both a first order autoregressive term as presented and a first order moving average. The results of these analyses led to consistent inferences in both cases.
} 
McGuinness 2012). This measure provides a crude but reliable measure of the size of the intra-party organizational mechanism and the associated difficulty with maintaining a parsimonious policy program with higher membership numbers. Overall, our first hypothesis predicts that a larger party membership leads to increased agenda instability for both parties. ${ }^{11}$

Our second independent variable captures the overall state of the economy through the UK misery index, a measure created through the addition of the unemployment and inflation rates. We chose this measure of economic circumstances instead of unemployment or inflation to create an ideologically neutral measure of the economy. This approach avoids the potential issues posed by associating specific parties with their assumed historical issue ownership, such as the relationship between the Labour party and unemployment that may make the effect of these individual measures somewhat ambiguous (Hibbs 1977; Budge and Farlie 1983). Misery on the other hand increases as the general economic condition worsens which should affect both Conservative and Labour governments in a similar manner. ${ }^{12}$

We also include a measure of the majority size calculated as the percentage seats the government party controls as the total number of seats in parliament varies from a low of 625 to a high of 659 seats making a count of seats inconsistent over time. ${ }^{13}$ Given our interest in

\footnotetext{
${ }^{11}$ Using logged membership instead of the raw number of members leads both the constitutive term and its interaction with government transition to become positive and significant, consistent with the first hypothesis.
}

${ }^{12}$ Alternative models using GDP as a general measure of the state of the economy produce the same general inferences, but were noticeably poorer fitting.

${ }^{13}$ We reran the analysis using the number of government seats rather than the percentage seats and found substantively similar results, although the effect of government size in nontransition years just barely dropped below conventional levels of significance. Likewise, using 
the government's ability to internally negotiate to find a parliamentary majority in the third set of hypotheses, we measure government size as the majority party's seats divided by the total number of seats in parliament and multiplied by 100 to ease interpretation. Nearly all governments (see Footnote 6) throughout the period control a majority of seats in the parliament. In the UK, a smaller majority size should arguably make for a less stable government, one unable to easily maintain a set policy program as party leaders are forced to induce MPs to support the party's policy proposals.

To account for partisan transitions in power, we make use of a party transition dummy variable. This measure is coded 1 in the first parliamentary year directly following an election that led to a change in the party majority. Analyses of the effect of both pre- and post- election dummy variables as possible alternative measures led to poorer fitting models and less fruitful results. ${ }^{14}$ However, given our theoretical expectations the real effect of elections on stability should only occur when an election leads to a change in government.

the logged percentage of seats, leads to substantively similar results and actually increases the level of significance to the $95 \%$ level for the effect in non-transition years.

${ }^{14} \mathrm{We}$ also performed the analysis with alternative specifications to check the robustness of our model. These include a dummy variable for change in the Chancellor of the Exchequer instead of party transitions as changes in Chancellors often represent changes in party direction even for incumbent parties. In this model the coefficients for each of the primary independent variables lead to the same inferences, but a poorer fitting model. We also test for an effect from the length of time in the opposition prior to a transition. This variable is negative and significant, but does not improve the model fit. Like Baumgartner et al (2009), we also ran a version of the analysis with a dummy variable indicating a change in the prime minister. The coefficient is negative, but never statistically significant. This alternative model 
We further include an interaction of our transition dummy variable with our party membership, misery index and majority size variables. We expect the effects of party membership to be in the same direction regardless of a transition. A higher party membership during a transition will likely produce a less radical shift in policy as a high membership also relates to a more ideologically centrist program and less consensus within the party (see Ceron 2013; Greene and Haber forthcoming). A high value for misery also leads to a unique effect; bad economic circumstances and a party transition will lead to a large and observable shift in policy as governments pursue alternate possible solutions to poor economic circumstance. Finally, government parties with a larger majority are more quickly capable of implementing its policy program and therefore, more dramatically destabilize the agenda in the first year following a transition.

Our final independent variable measures the number of years a party has been in power. This government age variable is a count variable from 1 that indicates how many years a party has controlled the prime minister. This measure captures our general belief that parties become better able to maintain a stable agenda over time when accounting for each of the above effects.

\section{Analyses}

Table 1 presents our auto-distributed lag model of agenda stability from 1945 to 2008 . Because of the nature of our variables, particularly the transition variable each of our

also leads to the same inferences, but a poorer fitting model with the party membership variable dropping below standard levels of statistical significance. 
independent variables is treated as contemporaneous. ${ }^{15}$ Figures $2-4$ present the predicted effects of each of our three interactions on agenda stability.

[insert Table 1 and Figures 2-4 about here]

The results from the analysis largely support our hypotheses and the logic behind our partisan explanations of agenda stability. As suggested in Hypothesis 1, the coefficient for party membership and its interaction with party transition are both positive. The marginal effect of party membership during a transition (presented at the bottom of Table 1$)^{16}$ is statistically different from zero at the $99 \%$ confidence level. The size of this effect is presented in Figure 2. This indicates that parties that have a larger membership in the electorate maintain a more stable agenda immediately following a partisan transition. By employing a bigger winning intra-party coalition the party cannot as easily break with the issue attention of the past government's political agenda. Interestingly, the effect is only statistically significant for the interaction with partisan transition. Party members may only dominate the party's agenda when the membership is paying the closest attention to its

\footnotetext{
${ }^{15}$ Alternative models using lagged variables other than transition led to a much poorer fitting model and only marginally significant results on our main independent variables. However, as it is unlikely that agenda stability is a main contributing factor in economic misery, party membership or majority size we believe that the use of contemporaneous effects is justified.

${ }^{16}$ As our model uses interaction terms to test the differing effects of our independent variables following partisan transitions the interacted terms as well as the transition variable cannot be directly interpreted. Specifically, the constitutive transition variable should not be interpreted as a generally positive effect on agenda stability following a transition as its total effect when considering the other variables it is interacted with in the model is generally negative.
} 
behavior in government: immediately following an electoral victory. The party can then more easily change its agenda in the years that follow a transition.

There is also evidence that the economy plays an important role in government agenda stability. As predicted by $\mathrm{H} 2 \mathrm{a}$, the positive and significant coefficient for the misery index indicates that greater economic misery increases the agenda stability. This demonstrates that as the economy performs poorly governments double down on their policies attempting to turn around economic circumstances through their existing policy program. The large, negative and significant marginal effect for misery during a partisan transition provides evidence for H2b. Following a partisan transition, the new party in government shifts the agenda to focus on different priorities than the prior government when faced with negative economic conditions. We present the substantive magnitude of these effects over different values of the misery index in Figure 3.

These results match case-specific evidence of party transitions under a poor economy. For example, when the Conservative party came into power under Thatcher in the 1979, the new government changed the agenda to focus on issues such as deregulation of financial markets, creating flexible labour markets and the privatization of state owned industries decreasing overall agenda stability. The previous Labour government had dedicated its policy attention primarily to relations with reducing unemployment, reforming Trade Unions and keeping prices and inflation low (“1979: Thatcher wins Tory landslide”). ${ }^{17}$

This finding also connects well with studies from an economic voting perspective. Seeking to appear accountable to their primary constituents, parties focus on the economic priorities of these groups when they enter into office (Hibbs 1977; Hicks and Swank 1992; Petrocik 1996). Furthermore, this increased instability indicates real difference between the

\footnotetext{
${ }^{17}$ See for example, the Labour and Conservative Party Manifestos from 1979, http://politicsresources.net/area/uk/man.htm, Accessed 2/17/2014/
} 
issues parties use to approach dealing with poor economic conditions. This difference suggests that choice between the government and opposition parties leads to real differences in government outcomes and that at least part of the motivation for economic voting, a desire for a change in policy by the electorate, takes place.

Like economic conditions and intra-party politics, the results support our expectations based on the size of the government's majority in parliament. In particular, we find evidence for $\mathrm{H} 3 \mathrm{a}$ that parties with a larger majority maintain a more stable agenda, although the coefficient is only statistically significant at the $90 \%$ confidence level. As we expect from $\mathrm{H} 3 \mathrm{~b}$, this effect is reversed for parties following a partisan transition; majority size has a negative effect and is significant at the $99 \%$ confident interval during a party transition. Parties with a larger majority are less affected by backbench rebellions and therefore can better focus the agenda on party priorities. Governments with smaller legislative delegations face difficulty with the more controversial elements of their agenda. We demonstrate these effects for different majority sizes -in Figure 4.

As the discussion of intra-party politics, the economy, and the party's parliamentary majority demonstrate, there is a clear effect for parties' time in office. The time between transitions is noteworthy, not just in how parties react to membership, misery and majority size, but in their general pattern of increasing stability over time. The years in power variable indicates that the longer a party stays in government the more stable the agenda generally becomes with a positive and significant effect at the $95 \%$ level. This matches $\mathrm{H} 4$ and indicates that governments professionalize and stabilize over time, increasing their ability to maintain a stable agenda. This likely indicates an effect from parties' greater expertise at implementing and maintaining their agenda with greater time in office.

Finally, lagged agenda stability is positive and significant at the $95 \%$ confidence level, but noticeably smaller than most autoregressive series. Given the inconclusive specification tests concerning the time series properties of our agenda stability variable this is, however, to 
be expected. Alternative models employing either a moving average or dropping the lagged agenda stability measure of the model produced the same inferences for each of our hypotheses, but were poorer fitting.

\section{Conclusion}

Our focus on agenda stability moves away from two of the most traditional methods for assessing partisan influence: attention to single issues and/or preferences over those issues. By focusing on a non-directional and aggregated measure of attention we can assess the degree of change in party programs based on intra-party and contextual characteristics without the need to measure preferences or make strong assumptions concerning the ownership of specific issues. Through our analyses we find clear evidence of significant and consistent ways through which parties' capacities and context influence the distribution of issue attention in the government's policy agenda. The effect for each of our primary explanatory variables is clearest immediately following partisan transitions. Parties with more members in the electorate increase agenda stability following a transition, although the number becomes less important later in the legislative cycle. Likewise, parties respond to economic conditions differently. New governments take a different approach than previous governments under poor economic conditions, yet parties maintain a stable agenda in response to a weak economy once they are in power. Finally, parties with a clearer legislative majority are more capable of dominating the legislative agenda than parties with smaller majorities. This effect is most pronounced following a transition when they can more quickly shift the government's agenda. This dominance allows governments later in the legislative cycle to maintain more consistent attention to their issue priorities.

The stability of the government's agenda also exhibits expected patterns over time with generally increasing agenda stability the longer a government is in power. For change to happen within government the economy must be booming. Parliamentary leaders with small 
government majorities must bargain for intra-party support, negotiate log rolls, or enforce party discipline across issues to enact their most preferred legislation. Governing parties are unlikely to change their agenda unless a strong economy allows them some additional leeway to expand the scope of their policy priorities. In addition, small majorities may be forced to compromise with minority groups to protect their greater agenda in office.

By focusing on a case with high levels of parliamentary discipline and still finding effect of intra-party variation, the results of our hypotheses on intra-party politics and parliamentary delegations should extend to countries with lower levels of discipline and less hierarchical parties. These results build on recent studies of party organizational change (Schumacher 2013; Schumacher et al. 2013) and parliamentary behavior (Ceron 2013) that find real evidence of intra-party politics on government behavior. However, future research will have to uncover the extent to which similar dynamics within and between parties occurs in multiparty democracies with regular governing coalitions. Issue level evidence suggests a prominent role for both government and opposition parties dependent on the coalition bargaining dynamics (e.g. Green-Pederson and Korgstrup 2008; Seeberg 2013).

Unlike previous studies from an agenda-setting perspective, these results paint a clear picture of aggregate partisan influence on the government's agenda based on party memberships, majorities, the economy and professionalization while in government. Our results help explain the previous lack of evidence of partisan influence. Previous studies searched for a partisan effect based on the issues that they assumed parties had a historical ownership over, largely finding that parties do not hold fixed preferences for policy on certain issues based on their party's ideological family (e.g. John et al 2014). Importantly, by only focusing on a single issue at a time, these previous analyses did not address our fundamental question directly; does the government's policy agenda change due to party transitions? We add a direct test of this question to the agenda-setting literature by demonstrating that parties are dynamic organizations which respond to current political contexts. While we have not 
directly linked parties' ideological preferences to the distribution of policy, we find straightforward evidence using our more nuanced approach that the political context (economic conditions) and the governing party's attributes lead to significant differences in agenda stability. Therefore, while previous studies generally suggest that the effect of party transition on the government agenda is minor on an issue by issue basis, we find the effect of transition on the overall agenda is in fact quite noticeable and dependent on the characteristics of parties themselves as well as their environment. Our research should serve as a complement to previous studies from an issue-by-issue basis by showing the aggregate influence of partisan change. Together, the issue level research and our aggregate results tell a rich story of the extent to which parties influence policy change. Future research would do well to recognize that the attributes of parties and not just their place on a left-right scale affect how they function and how they respond to different contexts such as the economy.

Our results have clear implications for voters and government accountability. Voters are increasingly pessimistic towards parties across the democratic world based at least in part on the belief that there is little difference between what parties do in government (Dalton 2008). Our findings optimistically suggest that there are real differences in issues attended to in Acts of Parliament following party transitions in government. However, parties see little reason to change their program once they have implemented their agenda in office. This evidence supports a model of accountability similar to the economic voting perspective where voters reward and punish parties based on economic performance. The logic follows that there is little reason to expect parties to change their behavior once they are in government with parties doubling-down on their agendas during hard economic times, when the size of their majority is strong and the longer they are in power.

Our analysis provides clear results consistent with our theory using a difficult case for within party influence. However, the research design limits our ability to make broad generalizations from this analysis. The results may not be fully robust to electoral contexts in 
which the relative location of parties' preferences is more important to voters than the issues they discuss (Green and Hobolt 2008). Future research would benefit from testing our more nuanced party based explanations in a broader range of countries that include multiparty governments or weak parliamentary discipline. More broadly, the results of our analysis indicate that scholars would benefit from adopting more discerning measures of party characteristics. Party leaders seeking to win future elections must contend with diverse intraparty groups, changing economic context, and bargain with MPs from within their party to maintain a stable agenda. 
Funding Acknowledgement: This work was supported by the Collaborative Research Center

884 Political Economy of Reforms (Projects C1 and C2), funded by the German Research

Foundation.

\section{References}

“1979: Thatcher wins Tory landslide” BBC News (April 5).

http://news.bbc.co.uk/2/hi/uk news/politics/vote 2005/basics/4393311.stm.

(Accessed February 17, 2014).

Adams, James. 1999. Policy divergence in multicandidate probabilistic spatial voting. Public Choice, 103, 103-22.

Adams, James, Andrea B. Haupt, and Heather Stoll. 2009. "What moves parties? The role of public opinion and global economic conditions in Western Europe."Comparative Political Studies 42 (5): 611-639.

Adams, James F. and Zeynep Somer-Topcu. 2009. "Do Parties Adjust Their Policies in Response to Rival Parties' Policy Shifts? Spatial Theory and the Dynamics of Party Competition in Twenty-Five Democracies.” British Journal of Political Science, 39, 825-846.

Alesina, Alberto and Howard Rosenthal. 1995. Partisan Politics, Divided Government and the Economy. Cambridge University Press.

Alt, James E., and Robert C. Lowry. 2000. “A dynamic model of state budget outcomes under divided partisan government." Journal of Politics, 62(4), 1035-1069.

Baumgartner, Frank, Sylvain Brouard, and Emiliano Grossman. 2009. “Agenda-Setting

Dynamics in France: Revisiting the 'partisan Hypothesis.”' French Politics 7(2): 7595. 
Bevan, Shaun, Peter John and Will Jennings. 2011. "Keeping Party Programmes on Track:

The Transmission of the Policy Agendas of Executive Speeches to Legislative Outputs in the United Kingdom.” European Political Science Review 3(3): 395-417.

Boydstun, Amber E., Shaun Bevan and Herschel F. Thomas III. 2014. "The Importance of Attention Diversity and How to Measure It.” Policy Studies Journal, 42(2): 173-196. Budge, Ian and Dennis Farlie. 1983. Explaining and Predicting Elections: Issue Effects and Party Strategies in Twenty-Three Democracies. Boston: George Allen and Unwin.

Budge. Ian. 1993. "Issues, Dimensions, and Agenda Change in Postwar Democracies:

Longterm trends in Party Election Programs and Newspaper Reports in Twenty-three Democracies" in Agenda Formation by William Riker, ed. Ann Arbor: University of Michigan Press.

Carey, John M. 2009. Legislative Voting and Accountability. Cambridge University Press.

Ceron, Andrea. 2013. "Brave Rebels Stay Home: Assessing the Effect of Intra-Party

Ideological Heterogeneity and Party Whip on Roll-Call Votes.” Party Politics (Published online January 24): 1-13.

Cox, Gary and Matthew McCubbins. 1994. Legislative Leviathan: Party Government in the House. Cambridge University Press.

Cox, Gary. 1987. The Efficient Secret: The Cabinet and the Development of Political Parties in Victorian England. Cambridge University Press.

Cox, Gary. 2000. “On the Effects of Legislative Rules.” Legislative Studies Quarterly 25 (2): 169-192.

Cross, William, and André Blais. 2012. "Who Selects the Party Leader?” Party Politics 18(2): $127-50$.

Dalton, Russell. 2008. Citizen Politics: Public Opinion and Political Parties in Advanced Industrial Democracies, $5^{\text {th }}$ Edition. CQ Press. 
De Vries, Kathryn and Sarah Hobolt. 2012. When Dimensions Collide: The Electoral Success of Issue Entrepreneurs. European Union Politics, 13, 246-268.

Döring, Herbert. 2001. "Parliamentary agenda control and legislative outcomes in Western Europe." Legislative Studies Quarterly: 145-165.

Döring, Herbert. 2003. "Party Discipline and Government Imposition of Restrictive Rules.” the Journal of Legislative Studies 9, 4: 147- 163.

Downs, Anthony. 1957. An Economic Theory of Democracy. New York: Harper.

Egan, Patrick. 2013. Partisan Priorities: How Issue Ownership Drives and Distorts American Politics. Cambridge University Press.

Green, Jane and Sara Hobolt. 2008. Owning the Issue Agenda: Party Strategies and Vote Choices in British Elections. Electoral Studies, 27, 460-476.

Green, Jane and Will Jennings. 2012a. "The Dynamics of Issue Competence and Vote for Parties In and Out of Power: An analysis of Valence in Britain, 1979-1997.” European Journal of Political Research 51: 469-503.

Green, Jane and Will Jennings. 2012b. "Valence as Macro-Competence: An Analysis of Mood in Party Competence Evaluations in Britain.” British Journal of Political Science 42:311-343.

Green-Pedersen, Christoffer, and Jesper Krogstrup. 2008. "Immigration as a Political Issue in Denmark and Sweden.” European Journal of Political Research 47(5): 610-34.

Green-Pedersen, Christoffer and Peter Mortensen. 2010. "Who Sets the Agenda and Who Responds to it in the Danish Parliament? A New Model of Issue Competition and Agenda-Setting.” European Journal of Political Research 49 (2): 257-281.

Greene, Zachary and Matthias Haber. Forthcoming. "Leadership Competition and Disagreement at Party National Congresses.” British Journal of Political Science (forthcoming). 
Harmel, Robert and Kenneth Janda. 1994. An Integrated Theory of Party Goals and Party

Change. Journal of Theoretical Politics, 6, 259-287.

Harmel, Robert, and Tan, Alexander. 2003. "Party Actors and Party Change: Does Factional

Dominance Matter?” European Journal of Political Research 42(3): 409-24.

Hibbs, D.A., Jr. 1977. "Political parties and macroeconomic policy", American Political

Science Review 71: 1467-1487

Hicks, A.M. and Swank, D.H. 1992. "Politics, institutions, and welfare spending in industrialized democracies, 1960-1982.” American Political Science Review 86: 658674

Huber, John D. and Charles Shipan. 2002. Deliberate Discretion? The Institutional Foundations of Bureaucratic Autonomy. Cambridge University Press.

Huber, John D. 1992. "Restrictive legislative procedures in France and the United States." The American Political Science Review: 675-687.

Huber, John D. 1996. Rationalizing Parliament: Legislative Institutions and Party Politics in France. Cambridge University Press.

Hug, Simon, and Tobias Schulz. 2007. "Left—Right Positions of Political Parties in Switzerland." Party Politics 13(3): 305-30.

Jennings, Will, Shaun Bevan and Peter John. 2011a. “The British Government's Political Agenda: the Speech from the Throne, 1911-2008.” Political Studies, 59(1): 74-98. Jennings, Will, Shaun Bevan, Arco Timmermans, Gerard Breeman, Sylvain Brouard, Laura Chaques, Christoffer Green-Pedersen, Peter John, Anna Palau and Peter B. Mortensen. 2011b. "Effects of the Core Functions of Government on the Diversity of Executive Agendas." Comparative Political Studies, 44(8): 1001-1030.

John, Peter, Shaun Bevan and Will Jennings. 2014. "Party Politics and Policy Agendas: the case of the United Kingdom' in Christoffer Green-Pedersen and Stefaan Walgrave 
(eds.) Agenda-Setting from a Policy Theory to a Theory of Politics. Chicago: Chicago University Press.

Kenig, Ofer. 2009. "Democratization of Party Leadership Selection: Do Wider Selectorates Produce More Competitive Contests?” Electoral Studies 28(2): 240-47.

Kitschelt, Herbert. 1989. “The Internal Politics of Parties: The Law of Curvilinear Disparity Revisited." Political Studies 37, 3: 400-421.

Laver, Michael. 1999. “Divided Parties, Divided Government.” Legislative Studies Quarterly 24: 5-29.

Lewis-Beck, Michael and Marie Stegmaier. 2000. "Economic Determinates of Political Outcomes.” Annual Review of Political Science 3: 183-219.

Lipset, and Stein Rokkan. 1967. Party Systems and Voter Alignments: Cross-National Perspectives. Toronto: The Free Press.

Martin, Lanny. 2004. “The Government Agenda in Parliamentary Democracies.” American Journal of Political Science 48 (3): 445-461.

McAtee, Andrea, Susan Webb Yackee, and David Lowery. 2003. "Reexamining the Dynamic Model of Divided Partisan Government." Journal of Politics 65 (2): 477-490.

McGuinness, Feargal. 2012. "Membership of UK Political Parties" House of Commons Library. Standard Note: SN/SG/5125.

Bélanger, Éric and Bonnie Meguid. 2008. "Issue Salience, Issue Ownership, and issue-based Vote Choice.” Electoral Studies 27: 477-491.

Mortensen, Peter Bjerre, Christoffer Green-Pedersen, Gerard Breeman, Laura ChaquésBonafont, Will Jennings, Peter John, Anna M. Palau, and Arco Timmermans. 2011."Comparing Government Agendas Executive Speeches in the Netherlands, United Kingdom, and Denmark." Comparative Political Studies, 44, 8: 973-1000.

Müller, Wolfgang and Kaare Strøm, eds. 2000. Coalition Governments in Western Europe.

Formatted: German (Germany) Oxford: Oxford University Press. 
O’Brien, Diana Z., and Yael Shomer. 2013. "A Cross-National Analysis of Party Switching.” Legislative Studies Quarterly 38(1): 111-41.

Petrocik, John. 1996. "Issue Ownership in Presidential Elections, with a 1980 Case Study.” American Journal of Political Science 40 (3): 825-850.

Powell, Bingham and Guy Whitten. 1993. “A Cross-National Analysis of Economic Voting: Taking Account of the Political Context." American Journal of Political Science 37, 2: 391-414.

Schmidt, Manfred. 2006. "When Parties Matter: A review of the possibilities and limits of partisan influence on public policy." European Journal of Political Research 30: 155183.

Schofield, Norman and Itai Sened. 2006. Multiparty Democracy: Elections and Legislative Politics. Cambridge University Press.

Schumacher, Gijs. 2013. When Does the Left do the Right Thing? A Study of Party Position Change on Welfare Policies. Party Politics (Online): 1-12.

Schumacher, Gijs, Catherine de Vries and Barbara Vis. 2013. "Why do Parties Change Position? Party Organization and Environmental Incentives.” Journal of Politics 75 (2): 464-477.

Seeberg, Henrik Bech. 2013. “The Opposition's Policy Influence through Issue Politicisation.” Journal of Public Policy 33(01): 89-107.

Seyd, Patrick and Paul Whiteley. 1992. Labour's Grassroots: The Politics of Party Membership. Clarendon Press.

Seyd, Patrick, and Paul Whiteley. 2004. "British Party Members An Overview.” Party Politics 10(4): 355-66.

Shomer, Yael. 2014. "What Affects Candidate Selection Processes? A Cross-National Examination." Party Politics 20(4): 533-46. 
Somer-Topcu, Zeynep. 2009. Timely Decisions: The Effects of Past National Elections on Party Policy Change. Journal of Politics, 71, 238-48.

Soroka, Stuart, and Christopher Wlezien. 2010. Degrees of democracy: Politics, public opinion, and policy. Cambridge University Press.

Spoon, Jae-Jae. 2011. Political Survival of Small Parties in Europe. University of Michigan Press.

Strøm, Kaare. 1990. Minority Government and Majority Rule. Cambridge: Cambridge University Press.

Tan, Alexander. 1997. "Party Change and Party Membership Decline: An Exploratory Analysis." Party Politics 3:363-377.

Tsebelis, George. 2002. Veto Players: How Political Institutions Work. Princeton: Princeton University Press.Whitten, Guy and Harvey Palmer. 1999. “Cross-National Analysis of Economic Voting.” Electoral Studies 18: 49-67.

Vliegenthart, Rens, and Stefaan Walgrave. 2011. "Content matters: The dynamics of parliamentary questioning in Belgium and Denmark." Comparative Political Studies 44(8): 1131-1159.

Whiteley, Paul, and Patrick Seyd. 2002. High-Intensity Participation: The Dynamics of Party Activism in Britain. University of Michigan Press.

Whiteley, Paul, Patrick Seyd, Jeremy Richardson, and Paul Bissell. 1994. "Explaining Party Activism: The Case of the British Conservative Party.” British Journal of Political Science 24(01): 79-94.

Williams, Laron, Katsunori Seki and Guy Whitten. Forthcoming. "You've Got Some Explaining To Do: The Influence of Economic Conditions and Spatial Competition on Party Strategy.” Political Science and Resarch Methods. 
Figure 1: Agenda Stability by Parliamentary Year, 1945-2008

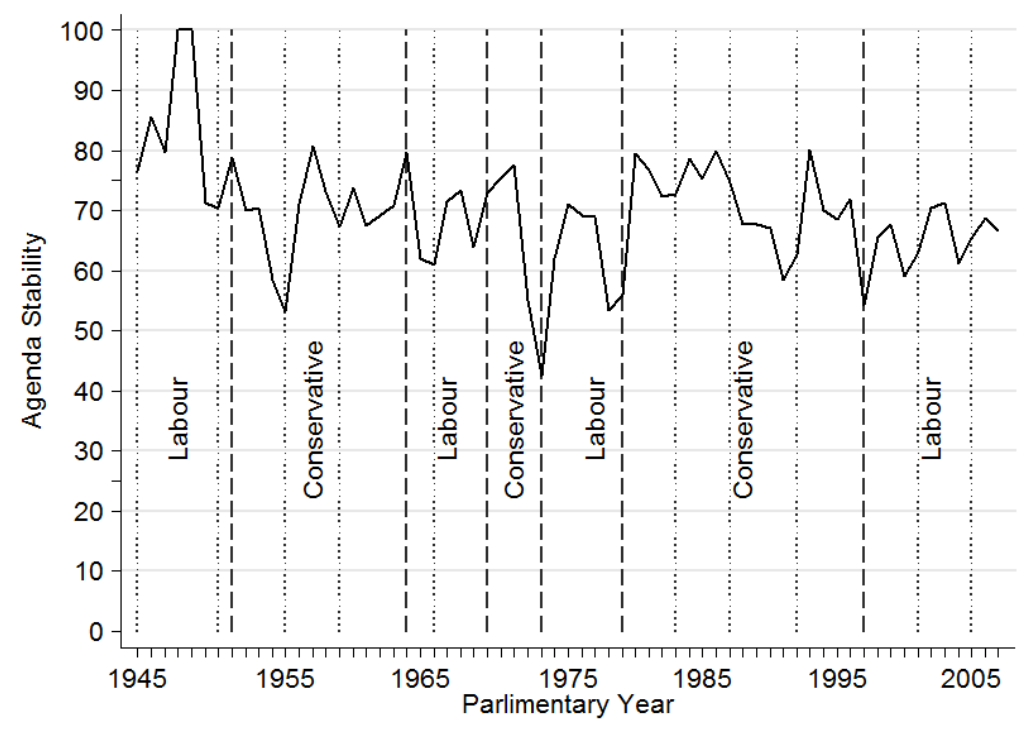


Figure 2: Predicted effect of Party Membership ${ }^{18}$

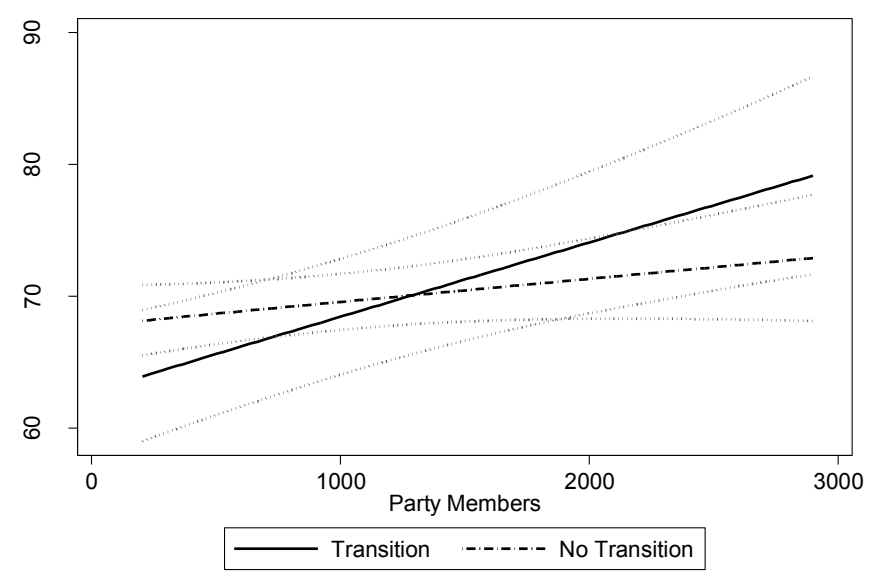

${ }^{18}$ The solid black line indicates the predicted change in agenda stability for increasing party membership size holding the independent variables at their mean values for the year following a party transition. The dashed line shows the predicted effect for agenda stability in nontransition years. The dotted lines around the solid line represent 95 percent confidence intervals based on simulations using 1,000 draws from the estimated variance-covariance matrix from the results presented in Table 1. Figures 3 and 4 use the same method for the predicted effects of misery and government seat share respectively. 
Figure 3: Predicted effect of Misery

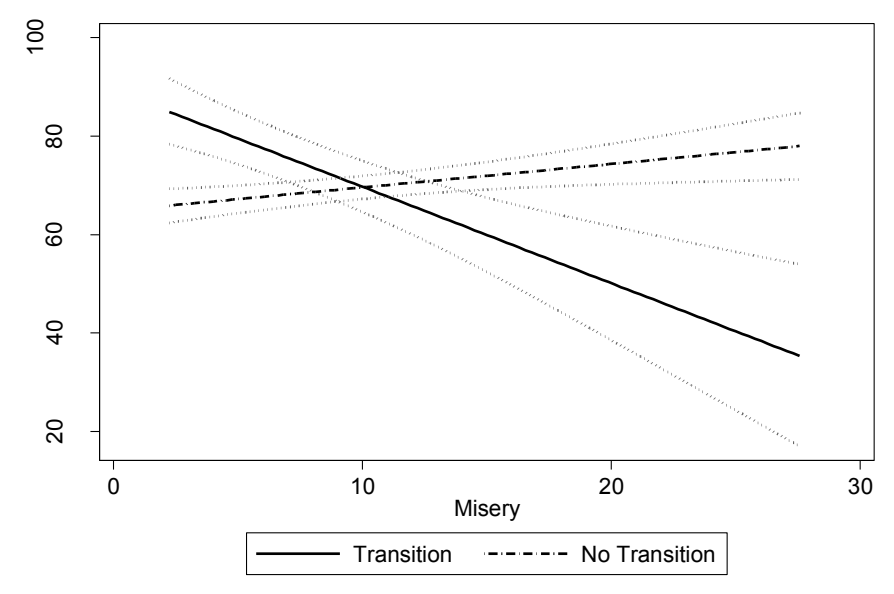


Figure 4: Predicted Effect of Government Seat Share

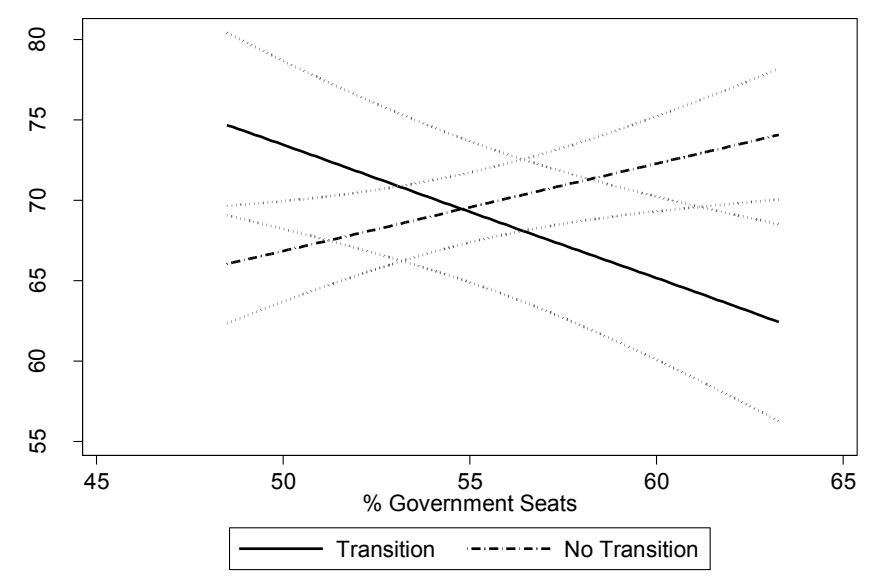


Table 1. Time Series Analyses of Agenda Stability, 1945-2008

\begin{tabular}{|c|c|}
\hline Agenda Stability $y_{\mathrm{t}-1}$ & $\begin{array}{l}0.361^{*} \\
(0.023)\end{array}$ \\
\hline Transition $_{\mathrm{t}} *$ Misery $_{\mathrm{t}}$ & $\begin{array}{l}-2.241^{* * *} \\
(0.000)\end{array}$ \\
\hline Transition $_{\mathrm{t}} *$ Membership $_{\mathrm{t}}$ & $\begin{array}{l}0.004^{*} \\
(0.046)\end{array}$ \\
\hline Transition $_{\mathrm{t}} *$ Majority Size $_{\mathrm{t}}$ & $\begin{array}{l}-1.361^{* * *} \\
(0.001)\end{array}$ \\
\hline Transition $_{t}$ & $\begin{array}{l}92.777^{* * *} \\
(0.000)\end{array}$ \\
\hline Misery Index $\mathrm{x}_{\mathrm{t}}$ (No Transition) & $\begin{array}{l}0.429^{*} \\
(0.033)\end{array}$ \\
\hline Party Membership ${ }_{t}$ (No Transition) & $\begin{array}{l}0.001 \\
(0.421)\end{array}$ \\
\hline Majority Size $_{\mathrm{t}}$ (No Transition) & $\begin{array}{l}46.208^{+} \\
(0.070)\end{array}$ \\
\hline Years in Power ${ }_{t}$ & $\begin{array}{l}0.514^{*} \\
(0.035)\end{array}$ \\
\hline Constant & $\begin{array}{l}9.585 \\
(0.576)\end{array}$ \\
\hline$R^{2}$ & $\begin{array}{l}0.491 \\
-224.711\end{array}$ \\
\hline
\end{tabular}

\begin{tabular}{ll}
\hline Marginal Effects & \\
\hline Misery Index (Transition) & $-1.811^{* * *}$ \\
& $(0.001)$ \\
Party Membership (Transition) & $0.005^{* *}$ \\
& $(0.004)$ \\
Majority Size (Transition) & $-0.899^{* *}$ \\
& $(0.005)$ \\
\hline
\end{tabular}

$p$-values in parentheses

${ }^{+} p<0.10,{ }^{*} p<0.05,{ }^{* *} p<0.01,{ }^{* * *} p<0.001$ 